\title{
Effect of Intraperitoneal Ketamine as Postoperative Analgesia in Laparoscopic Cholecystectomy
}

\author{
Ahmed M. Shawky, Ali A.A.A. Essa, Ahmed A.E.A. Emam \\ Department of Anesthesia and Intensive Care, Faculty of Medicine, Al-Azhar University \\ Corresponding author: Ahmed A.E.A. Emam, Email: emam34678@ gmail.com, Mobile: 01027221833
}

\begin{abstract}
Background: Laparoscopic surgery is gaining popularity so different modalities of pain management should be used as patients experience postoperative pain of different sources especially from the abdomen, back and shoulder region which is severe especially in first postoperative hours.

Objective: We aimed to evaluate effect of intraperitoneal instillation of ketamine and normal saline on postoperative pain and analgesic requirements after laparoscopic cholecystectomy.

Patients and Methods: Forty patients undergoing laparoscopic cholecystectomy were randomly allocated and divided into two groups, The ketamine intraperitoneal (KIP) group ( $\mathrm{n}=20$ patients), in which $0.5 \mathrm{mg} / \mathrm{kg}$ ketamine diluted in $30 \mathrm{ml}$ normal saline was instilled intraperitoneally, The saline intraperitoneal (SIP) group $(\mathrm{n}=20$ patients), in which $30 \mathrm{ml}$ of normal saline was instilled intraperitoneally. Patients receive these drugs as follow, $16 \mathrm{ml}$ in gall bladder fossa while other $14 \mathrm{ml}$ under copula of diaphragm on both sides while patients were placed in 15-20-degree trendelenburg position. This was done before patients recovered from anesthesia, then patients extubated and transferred to ward. Patients were evaluated according to VAS ، time to first analgesic and total analgesic requirements during 24 hours post-operative.

Results: Our results showed that usage of ketamine decreases postoperative pain and analgesic consumption in the first 24 hours after surgery along with longer pain free period compared to patients who were given bupivacaine after laparoscopic cholecystectomy. In our study ketamine $0.5 \mathrm{mg} / \mathrm{kg}$ was safely used as we did not observe any sign of toxicity.

Conclusion: Intraperitoneal instillation of local anesthetic is an easy, cheap and safe method which provides good analgesia in the immediate postoperative period after laparoscopic surgery. Ketamine is highly effective in postoperative pain control in laparoscopic cholecystectomy without any hazards on patients.
\end{abstract}

Keywords: Adverse Drug Reactions, Visual Analogue Scale, N-methyl-D-aspartate, Anesthesiologist

\section{INTRODUCTION}

Laparoscopic cholecystectomy is presumed to be the method of choice for gall bladder surgery. While laparoscopic cholecystectomy is concerned to induce less pain than open surgery, pain is the principal cause of delayed hospital discharge after laparoscopic cholecystectomy ${ }^{(1)}$.

Patients undergoing laparoscopic procedures experience postoperative pain especially in the abdomen, back and shoulder region which require more attention. Pain intensity usually peaks during first postoperative hours.

There are three components of pain after laparoscopic surgeries: Visceral pain which results from the stretching of the intra-abdominal cavity. Shoulder pain which results from phrenic nerve irritation caused by residual carbon dioxide in the peritoneal cavity. Somatic pain due to small surgical incision, which has much less pain intensity ${ }^{(2)}$.

Various multimodal approaches have, therefore, been tried to improve postoperative pain. These include parenteral analgesics, local infiltration with local anesthetics, epidural and intrathecal opioids and local anesthetics, interpleural and intercostal nerve blocks as well as intraperitoneal routes that in turn has been explored with local anesthetics and opioids ${ }^{(3)}$.
$\mathrm{N}$-methyl-D-aspartate (NMDA) receptor activation is considered one of the mechanisms of postoperative pain and hypersensitivity through both peripheral and central effects ${ }^{(4)}$.

Ketamine is a non-competitive NMDA receptor antagonist with hypnotic and analgesic activity, which can be administrated in many ways ${ }^{(5)}$.

It simply crosses from most tissue membranes that lead to easy absorption. It also has early onset and short duration of action and because of peripheral action at both opioid and NMDA receptor, its peripheral application has been recently evaluated in many studies ${ }^{(6)}$.

It seems that intra-peritoneal administration of ketamine could be an acceptable alternative to local anesthetics such as Bupivacaine for postoperative analgesia in laparoscopic surgery ${ }^{(7)}$.

\section{AIM OF THE WORK}

The aim of this study is to evaluate the effect of intra-peritoneal instillation of ketamine $0.5 \mathrm{mg} / \mathrm{kg}$ in patients undergoing laparoscopic cholecystectomy on post-operative analgesia as a primary outcome. The secondary outcome is the total analgesic consumption in the first 24 hours postoperatively. 


\section{PATIENTS AND METHODS}

Design: After approval of the Medical Ethical Committee at Al-Azhar University hospitals, department of Anesthesiology, 40 patients aged 20-50 years of ASA physical status I or II, of either sex scheduled for surgical operation under general anesthesia are enrolled in this prospective controlled double blinded randomized study. Information about the study was given comprehensively both orally and in written form to the patients. All patients gave their written informed consents prior to their inclusion in the study.

Patients were randomized into the two groups: 1- The ketamine intraperitoneal (KIP) group ( $\mathrm{n}=20$ patients), in which $0.5 \mathrm{mg} / \mathrm{kg}$ ketamine diluted in $30 \mathrm{ml}$ normal saline was instilled intraperitoneally. 2- The saline intraperitoneal (SIP) group $(n=20$ patients), in which $30 \mathrm{ml}$ of normal saline was instilled intraperitoneally.

Setting: The study was carried out in AlAzhar University Hospitals.

Exclusion criteria: Patients with cardiovascular, pulmonary, psychological or neurological diseases; Patients known to be epileptic; Patients who have an increase in intracranial tension; Patients with known allergies to the study drug (Ketamine); Patients with recent NSAID medication; Patients with acute cholecystitis; Patients with any perioperative complications; Duration of operation more than 2 hours; Patients in whom the procedure will be converted to open cholecystectomy.

Preoperative evaluation: The patients were screened for suitability by: History: including assessment of the cardio-respiratory status. Physical examination: chest and heart auscultation and airway assessment. Investigations: complete blood picture, coagulation profile, liver function, kidney function and ECG.

\section{Patient monitoring (standard} monitoring): Pulse oximetry, ECG, Non-invasive blood pressure monitoring, 5min, interval, Capnogram.

Materials: Monitors for vital signs: Electrocardiogram (ECG), noninvasive blood pressure (NIBP), Pulse Oximetry $(\mathrm{SpO} 2)$ and Capnogram (etCO2). Anesthetic machine: \{DRAGER Fabius GS\}, Resuscitation equipments (e.g. defibrillator and pacemaker) and drugs, Drugs for premedication: Midazolam $(0.03 \mathrm{mg} / \mathrm{kg})$, Ketamine $10 \mathrm{ml}(50 \mathrm{mg} / \mathrm{ml})$.

Statistical analysis: Recorded data were analyzed using the statistical package for social sciences, version 20.0 (SPSS Inc., Chicago, Illinois, USA). Quantitative data were expressed as mean \pm standard deviation (SD). Qualitative data were expressed as frequency and percentage. The following tests were done: Independent-samples ttest of significance was used when comparing between two means. Mann Whitney $U$ test: for two-group comparisons in non-parametric data. Chi-square (x2) test of significance was used in order to compare proportions between two qualitative parameters. The confidence interval was set to $95 \%$ and the margin of error accepted was set to $5 \%$. So, the p-value $<0.05$ was considered significant. The sample size was calculated based on an initial pilot study of 10 participants ( 5 in each group). We considered that a30\% decrease in the rate of severe pain (primary study) would be of clinically significant.

\section{RESULTS}

Table (1): Comparison between ketamine intraperitoneal group and Saline intraperitoneal group according to demographic data.

\begin{tabular}{|c|c|c|c|c|}
\hline $\begin{array}{c}\text { Demographic } \\
\text { data }\end{array}$ & \begin{tabular}{|c|} 
Ketamine \\
intraperitoneal \\
group $(\mathrm{N}=20)$ \\
\end{tabular} & \begin{tabular}{|c|} 
Saline \\
intraperitoneal \\
group $(\mathrm{N}=20)$ \\
\end{tabular} & $t / x 2 \#$ & p-value \\
\hline $\begin{array}{l}\text { Age (years) } \\
\text { Mean } \pm \text { SD } \\
\text { Range }\end{array}$ & $\begin{array}{c}42.80 \pm 5.19 \\
33-50\end{array}$ & $\begin{array}{c}40.25 \pm 5.82 \\
29-50\end{array}$ & 1.146 & 0.249 \\
\hline $\begin{array}{l}\text { Weight }(\mathrm{kg}) \\
\text { Mean } \pm \text { SD } \\
\text { Range }\end{array}$ & $\begin{array}{c}77.10 \pm 5.46 \\
65-88\end{array}$ & $\begin{array}{c}74.75 \pm 5.22 \\
65-85\end{array}$ & 1.937 & 0.172 \\
\hline $\begin{array}{l}\text { Sex } \\
\text { Male } \\
\text { Female }\end{array}$ & $\begin{array}{c}3(15.0 \%) \\
17(85.0 \%)\end{array}$ & $\begin{array}{c}4(20.0 \%) \\
16(80.0 \%)\end{array}$ & $0.173 \#$ & 0.677 \\
\hline $\begin{array}{l}\text { ASA } \\
\text { I } \\
\text { II }\end{array}$ & $\begin{array}{c}16(80.0 \%) \\
4(20.0 \%)\end{array}$ & $\begin{array}{c}14(70.0 \%) \\
6(30.0 \%)\end{array}$ & $0.533 \#$ & 0.465 \\
\hline
\end{tabular}

Table (2): Comparison between ketamine intraperitoneal group and Saline intraperitoneal group according to time to tracheal extubation (min).

\begin{tabular}{|l|c|c|c|c|}
\hline $\begin{array}{c}\text { Time to } \\
\text { tracheal } \\
\text { extubatio } \\
\text { n (min) }\end{array}$ & $\begin{array}{c}\text { Ketamine } \\
\text { intraperitonea } \\
\text { I group (N=20) }\end{array}$ & $\begin{array}{c}\text { Saline } \\
\text { intraperitonea } \\
\text { i group (N=20) }\end{array}$ & t-test & $\begin{array}{c}\mathbf{p}- \\
\text { value }\end{array}$ \\
\hline Mean \pm SD & $5.55 \pm 0.60$ & $4.25 \pm 0.79$ & 34.34 & $<0.001$ \\
\hline Range & $5-7$ & $3-6$ & 2 & \\
\hline
\end{tabular}


Table (3): Comparison between ketamine intraperitoneal group and Saline intraperitoneal group according to VAS.

\begin{tabular}{|l|c|c|c|c|}
\hline \multicolumn{1}{|c|}{ VAS } & $\begin{array}{c}\text { Ketamine } \\
\text { intraperitoneal } \\
\text { group (N=20) }\end{array}$ & $\begin{array}{c}\text { Saline } \\
\text { intraperitoneal } \\
\text { group (N=20) }\end{array}$ & z-test & p-value \\
\hline $\begin{array}{l}\text { After 1h } \\
\text { Median (IQR) } \\
\text { Range }\end{array}$ & $\begin{array}{c}\text { (10.75) } \\
0-3\end{array}$ & $\begin{array}{c}4(2) \\
2-7\end{array}$ & 66.676 & $<0.001$ \\
\hline $\begin{array}{l}\text { After 2h } \\
\text { Median (IQR) } \\
\text { Range }\end{array}$ & $1(1)$ & $2(1)$ & 35.286 & $<0.001$ \\
\hline $\begin{array}{l}\text { After 4h } \\
\text { Median (IQR) } \\
\text { Range }\end{array}$ & $0-2$ & $1-5$ & & \\
\hline $\begin{array}{l}\text { After 8h } \\
\text { Median (IQR) } \\
\text { Range }\end{array}$ & $0-2$ & $2(1)$ & 45.011 & $<0.001$ \\
\hline $\begin{array}{l}\text { After 12h } \\
\text { Median (IQR) }\end{array}$ & $0(0)$ & $1(0)$ & 190.000 & $<0.001$ \\
Range & $0-0$ & $1(0)$ & 361.000 & $<0.001$ \\
\hline $\begin{array}{l}\text { After 24h } \\
\text { Median (IQR) } \\
\text { Range }\end{array}$ & $0(0)$ & $1(0)$ & 44.333 & $<0.001$ \\
\hline
\end{tabular}

Table (4): Comparison between ketamine intraperitoneal group and Saline intraperitoneal group according to time to first request for analgesia.

\begin{tabular}{|l|c|c|c|c|}
\hline $\begin{array}{c}\text { Time to first } \\
\text { request for } \\
\text { analgesia } \\
\text { (hr) }\end{array}$ & $\begin{array}{c}\text { Ketamine } \\
\text { intraperitoneal } \\
\text { group (N=20) }\end{array}$ & $\begin{array}{c}\text { Saline } \\
\text { intraperitoneal } \\
\text { group (N=20) }\end{array}$ & t-test & p-value \\
\cline { 1 - 3 } Mean \pm SD & $3.95 \pm 1.05$ & $1.10 \pm 0.31$ & \multirow{2}{*}{135.673} & $<0.001$ \\
\hline Range & $2-6$ & $1-2$ & \\
\hline
\end{tabular}

Table (5): Comparison between ketamine intraperitoneal group and Saline intraperitoneal group according to morphine (mg/24h).

\begin{tabular}{|l|c|c|c|c|}
$\begin{array}{c}\text { Total dose of } \\
\text { Morphine post } \\
\text { operatively } \\
(\mathbf{m g} / \mathbf{2 4 h})\end{array}$ & $\begin{array}{c}\text { Ketamine } \\
\text { intraperitoneal } \\
\text { group (N=20) }\end{array}$ & $\begin{array}{c}\text { Saline } \\
\text { intraperitoneal } \\
\text { group (N=20) }\end{array}$ & t-test & p-value \\
\hline Mean \pm SD & $12.00 \pm 2.51$ & $18.25 \pm 2.45$ & 63.503 & $<0.001$ \\
\hline Range & $10-15$ & $15-20$ & \\
\hline
\end{tabular}

Table (6): Comparison between ketamine intraperitoneal group and Saline intraperitoneal group according to sedation score.

\begin{tabular}{|c|c|c|c|c|}
\hline $\begin{array}{l}\text { Sedation } \\
\text { score }\end{array}$ & $\begin{array}{c}\text { Ketamine } \\
\text { intraperitoneal } \\
\text { group }(\mathrm{N}=\mathbf{2 0})\end{array}$ & $\begin{array}{c}\text { Saline } \\
\text { intraperitoneal } \\
\text { group }(N=20)\end{array}$ & z-test & p-value \\
\hline $\begin{array}{l}\text { Recovery } \\
\text { Median (IQR) } \\
\text { Range } \\
\end{array}$ & $\begin{array}{l}1(0) \\
0-2 \\
\end{array}$ & $\begin{array}{c}0.50(1) \\
0-1 \\
\end{array}$ & 12.667 & $<0.001$ \\
\hline $\begin{array}{l}30 \text { min } \\
\text { Median (IQR) } \\
\text { Range }\end{array}$ & $\begin{array}{c}0.50(1) \\
0-2\end{array}$ & $\begin{array}{c}0(0) \\
0-1 \\
\end{array}$ & 4.586 & 0.039 \\
\hline $\begin{array}{l}2 \mathrm{~h} \\
\text { Median (IQR) } \\
\text { Range }\end{array}$ & $\begin{array}{c}0(0) \\
0-0\end{array}$ & $\begin{array}{c}0(0) \\
0-0\end{array}$ & 0.000 & 1.000 \\
\hline $\begin{array}{l}4 \mathrm{~h} \\
\text { Median (IQR) } \\
\text { Range }\end{array}$ & $\begin{array}{c}0(0) \\
0-0\end{array}$ & $\begin{array}{c}0(0) \\
0-0\end{array}$ & 0.000 & 1.000 \\
\hline
\end{tabular}

Table (7): Comparison between ketamine intraperitoneal group and Saline intraperitoneal group according to complications.

\begin{tabular}{|l|c|c|l|l|}
\hline Complications & $\begin{array}{c}\text { Ketamine } \\
\text { intraperitoneal } \\
\text { group (N=20) }\end{array}$ & $\begin{array}{c}\text { Saline } \\
\text { intraperitoneal } \\
\text { group (N=20) }\end{array}$ & $\mathbf{x 2}$ & p-value \\
\hline $\begin{array}{l}\text { Nausea } \\
\text { No }\end{array}$ & $10(50.0 \%)$ & $13(65.0 \%)$ & & \\
$\quad$ Yes & $10(50.0 \%)$ & $7(35.0 \%)$ & 0.921 & 0.337 \\
\hline $\begin{array}{l}\text { Vomiting } \\
\text { No }\end{array}$ & $\begin{array}{c}15(75.0 \%) \\
\text { Yes }\end{array}$ & $\begin{array}{c}17(85.0 \%) \\
3(15.0 \%)\end{array}$ & 0.625 & 0.429 \\
\hline
\end{tabular}

Table (8): Comparison between ketamine intraperitoneal group and Saline intraperitoneal group according to patient's satisfaction.

\begin{tabular}{|c|c|c|c|c|}
\hline $\begin{array}{c}\text { Patient } \\
\text { Satisfaction }\end{array}$ & $\begin{array}{c}\text { Ketamine } \\
\text { intraperitoneal } \\
\text { group }(\mathbf{N}=\mathbf{2 0})\end{array}$ & \begin{tabular}{|c|} 
Saline \\
intraperitoneal \\
group $(\mathbf{N}=\mathbf{2 0})$
\end{tabular} & $\mathrm{x} 2$ & p-value \\
\hline Satisfied & $12(60.0 \%)$ & $4(20.0 \%)$ & \multirow{3}{*}{9.474} & \multirow{3}{*}{0.009} \\
\hline Average & $8(40.0 \%)$ & $11(55.0 \%)$ & & \\
\hline Unsatisfied & $0(0.0 \%)$ & $5(25.0 \%)$ & & \\
\hline
\end{tabular}

\section{DISCUSSION}

After any surgery rapid restoration of patient's autonomy, shortened hospital stay, decreased morbidity, costs are directly related to improved postoperative pain management. Postoperative pain is unpredictable, which explains the need for systematic prevention of pain before patient wakes up from anesthesia ${ }^{(9)}$.

Improved postoperative pain treatment using opioid-sparing regimens may facilitate a high success rate of outpatient laparoscopic cholecystectomy, as both pain and opioids may induce nausea. Acute hemodynamic response usually occurs during the period of the pneumoperitoneum in patients undergoing laparoscopic surgical procedures in the form of increased blood pressure \&heart rate ${ }^{(10)}$.

Pre-emptive analgesia has gained popularity and its role in the control of pain has been extensively studied in this context. It involves administration of analgesic regime before the onset of noxious stimulus, with the goal of preventing sensitization of C.N.S to subsequent stimuli that amplify pain ${ }^{(11)}$.

These changes are consequent to hypercarbia-induced release of catecholamines, vasopressin, or both. In addition, the shifts in intravascular volume resulting from the 
Trendelenberg's position can lead to hemodynamic alterations during laparoscopy ${ }^{(10)}$.

There are many types of pain after laparoscopic cholecystectomy. Discomfort due to carbon dioxide insufflation and scapular pain especially when exaggerated reverse Trendelenberg's position is used, tends to appear during the night after surgery.

Infiltration of local anesthetics decreases scapular pain. Visceral pain has its maximal intensity during the first hour and is exacerbated by coughing, respiratory movements and mobilization. It requires opioid administration when patient recovers from anesthesia ${ }^{(9)}$.

In our study 40 patients, scheduled for elective laparoscopic cholecystectomy surgeries ASA I\&II were enrolled in the study. Patients were divided into 2 groups; each of them contains 20 patients:

1- Group A: Patients received intraperitoneal Ketamine $(0.5 \mathrm{mg} / \mathrm{kg})$ diluted in $30 \mathrm{ml}$ normal saline.

2- Group B: Patients received intraperitoneal Saline $30 \mathrm{ml}$ 0.9\%.

There was no statistically significant difference between the two groups of the study regarding their demographic data (age, sex, weight and ASA classification).

Our data also showed that intraperitoneal ketamine infiltration is associated with reduction of both postoperative pain, and the analgesic requirements in patients undergoing laparoscopic cholecystectomy. Intraperitoneal ketamine administration led to more effective pain control than the intraperitoneal Saline instillation especially in the early postoperative period.

As regard to time to tracheal extubation, we observed that patients in the SIP group were extubated earlier than the patients in the KIP group (4.25 \pm 0.79 VS 5.55 \pm 0.60$)$ respectively, because of the analgesic effect of ketamine and systemic absorption that could potentiate the effect of anesthetic drugs.

As regard postoperative pain (VAS score), it showed lower results in ketamine group than in saline group after 1 hour as it was (1(0.75) VS
4(2)) respectively and even after 24 hours (0(0) VS $1(0))$ respectively.

These results agreed with a study done by Goma et al. ${ }^{(7)}$ in which Intraperitoneal ketamine, which blocks peripheral NMDA receptors, may reduce the postoperative analgesic needs in morbidly obese patients following bariatric surgery in comparison with intraperitoneal lidocaine.

Also, Moharari et al. reported that intraperitoneal instillation of $0.5 \mathrm{mg} / \mathrm{kg}$ ketamine in elective laparoscopic cholecystectomy significantly reduces the postoperative pain and the analgesic requirement ${ }^{(6)}$.

Klimscha et al. also demonstrated that intraperitoneal ketamine did not have any antinociceptive effects ${ }^{(11)}$. On the other hand, Crisp et al. suggested that intraperitoneal ketamine produced the antinociceptive effects ${ }^{(12)}$.

AS regard time to first analgesic, it was more prolonged in ketamine group than in saline group (3.95 $\pm 1.05 \mathrm{VS} 1.10 \pm 0.31)$ respectively.

As far total dose of morphine required, it was less in ketamine group and higher in saline group (12.00 $\pm 2.51 \mathrm{VS} 18.25 \pm 2.45)$ respectively.

As regard postoperative sedation score, it showed that patients in ketamine group were sedated at time of recovery and after 30 minutes in comparison to saline group. This sedation may be due to the depressant effect of ketamine on central nervous system and the antagonism of NMDA receptors.

There was no statistical difference between 2 groups after 2 hours and after 4 hours.

High ketamine lipo-solubility results in rapid bioavailability in the central nervous system, resulting in rapid onset of action ${ }^{(13)}$.

This rapid onset of sedation was observed in the present study and is similar to that reported in other studies published by Lee et al. (14), Naccarato et al. ${ }^{(15)}$ and Settle et al. ${ }^{(16)}$.

There was no statistical significant difference between 2 groups as regard to postoperative complications (nausea, vomiting).

As regard to patient satisfaction, it was high in ketamine group than in saline group $(60 \%$ vs $20 \%$ ) respectively. 
In our present study, hemodynamics including mean arterial blood pressure (MAP), heart rate and respiratory rate were more stable in ketamine group than in saline group throughout all 24 hours postoperative. That may be due to prolonged pain free periods with low VAS which was easily controlled by low dose analgesics.

In our study ketamine improved the quality of analgesia, with fewer requirements for postoperative analgesics after laparoscopic cholecystectomy.

The timing of the administration of the local anesthetic during surgery is a matter of debate. Some trials suggested that early instillation of intraperitoneal local anesthetics provided better postoperative pain control compared with instillation at the end of surgery, but was contradicted by other trials ${ }^{(17)}$.

In our study, we chose to use the instillation of drugs at the end of the surgery.

A meta-analysis by Boddy et al. (18) established the efficacy of intraperitoneal local anesthetics in reducing early post laparoscopic cholecystectomy pain and no adverse events related to local anesthetic toxicity were reported similarly in our study, also no adverse events due to intraperitoneal instillation of saline were observed.

Laparoscopic cholecystectomy causes less stress response than open surgery. This was proved by several studies which showed that a hormonal response to cholecystectomy occurred in both procedures studied, but the surgical stress was higher and longer lasting in open surgery compared to the laparoscopic approach ${ }^{(19)}$.

In our study, we did not observe any unwanted effects of study drugs like anaphylaxis, nausea, vomiting, pruritus and hypotension in the studied patients in ketamine group. May be due to the fact that ketamine blocks NMDA receptors, which lie in both emetic pathways and structures associated with the final common pathway for vomiting. NMDA antagonists have the potential to be broad-spectrum antiemetic ${ }^{(20)}$.

One of the disadvantages of the present study is prolongation of extubation time in ketamine group. It seems that intraperitoneal ketamine leads to systemic absorption that could potentiate the effect of anesthetic drugs ${ }^{(21)}$.

\section{CONCLUSION}

This study suggest that intraperitoneal instillation of ketamine is superior to saline for the relief of postoperative pain in patients undergoing laparoscopic surgery without any significant increase in adverse events. Longer pain free periods had been observed in ketamine group if compared with saline group with less VAS and more rapid onset of analgesia. After recovery patients were calm and sedated with the use of ketamine and not agitated just like patients of saline group.

\section{REFERENCES}

1. Esmat ME, Elsebae MM, Nasr MM, Elsebaie SB (2006): Combined low pressure pneumoperitoneum and intraperitoneal infusion of normal saline for reducing shoulder tip pain following laparoscopic cholecystectomy. World J Surg., 30:1969- 1973.

2. Butala BP, Shah VR, Nived K (2013): Randomized double blind trial of intraperitoneal instillation of bupivacaine and morphine for pain relieve after laparoscopic gynecological surgeries. Saudi J Anaesth., 7:18-23.

3. Sehgal V, Bajwa SJ, Sehgal R, Bajaj A, Khaira U, Kresse V (2013): Polypharmacy and potentially inappropriate medication use as the precipitating factor in readmissions to the hospital. J Family Med Prim Care., 2:194-9.

4. McRoberts JA (2001): Role of peripheral Nmethyl-D-aspartate (NMDA) receptors in visceral nociception in rats. Gastroenterology, 120: $1737-1748$.

5. Laskowski K, Stirling A, McKay WP et al. (2011): A systematic review of intravenous ketamine for postoperative analgesia. Canadian Journal of Anaesthesia, 58(10): 911-23.

6. Moharari RS, Najafi A, Khajavi MR, Moharari GS, Nikoobakht MR (2010): Intraurethral instillation of ketamine for male rigid cystoscopy. J Endourol., 24(12):2033-6. 
7. Goma HM and Elhamid BA (2015): Intra Peritoneal S Ketamine reduces Postoperative Analgesic Requirements in Morbidly Obese Patients A Controlled Study. Enliven: J Anesthesiol Crit Care Med., 2(5): 014.

8. Klimscha W, Horvath G, Szikszay M, Dobos I, Benedek G (1998): Antinociceptive effect of the $\mathrm{S}(1)$-enantiomer of ketamine on carrageenan hyperalgesia after intraperitoneal administration in rats. Anesth Analg., 1998; 86:561-5.

9. Mraovic B, Jurisic T, Kogler-Majeric V, Sustic A (1997): Intraperitoneal bupivacaine for analgesia after laparoscopic cholecystectomy. Acta Anesthesia Scand., 41:193-96.

10. Mann C, Boccara G, Pouzeratte Y (1999): The relationship among carbondioxide pneumoperitoneum, vasopressin release, and haemodynamic. Changes. Anesth Analg., $89: 278-283$

11. Anjum S, Wasim S, Sabeeha G (2015): Effect of Magnesium Sulphate on postoperative pain in laparoscopic cholecystectomy. International Journal of Advanced Research, 3(10): 813-818.

12. Crisp T, Perrotti JM, Smith DL, Stafinsky JL, Smith DJ (1991): The local monoaminergic dependency of spinal ketamine. Eur. J. Pharmacol., 194:167-72.

13. Kohn DF, Wixson SK, White WJ, Benson GJ (1997): Anesthesia and Analgesia in Laboratory Animals. New York: Elsevier Science.

14. Lee VK, Flynt KS, Haag LM, Taylor DK (2010): Comparison of the Effects of Ketamine, Ketamine-Medetomidine, and Ketamine- Midazolam on Physiologic Parameters and Anesthesia-Induced Stress in Rhesus (Macaca mulatta) and Cynomolgus (Macaca fascicularis) Macaques. J Am Assoc Lab Anim Sci., 49:57-63.

15. Naccarato EF and Hunter WS (1979): Anaesthetic effects of various ratios of ketamine and xylazine in rhesus monkeys (Macaca mulatta). Lab Anim., 13:317-9.
16. Settle TL, Rico PJ, Lugo-Roman LA (2010): The effect of daily repeated sedation using ketamine or ketamine combined with medetomidine on physiology and anesthetic characteristics in Rhesus Macaques. J Med Primatol., 39: 50-7.

17. Barczynski M, Konturek A, Herman RM (2006): Superiority of preemptive analgesia with intraperitoneal instillation of bupivacaine before, rather than after, the creation of pneumoperitoneum for laparoscopic cholecystectomy: a randomized, double-blind, placebo-controlled study. Surg Endosc., 20:1088-1093.

18. Boddy AP, Mehta S, Rhodes M (2006): The effect of intraperitoneal local anesthetic in laparoscopic cholecystectomy: A systematic review and meta-analysis. Anesth Analg., 103: 682-8.

19. Eduardo C, Elisangela NR, Ana MH, Juverson TA, Ricardo P, Alex AS (2005): Evaluation of the response of cortisol, corticotropin and blood platelets kinetics after laparoscopic and open cholecystectomy. Acta Cir. Bras., 20(5): 18-29.

20. Lucot JB (1998): Effects of N-methyl-daspartate antagonists on different measures of motion sickness in cats. Brain Res Bull., 47:407-411.

21. Tverskoy M, Oren M, Vaskovich M (1996): Ketamine enhances local anesthetics and analgesic effects of bupivacaine by peripheral mechanism: a study in postoperative patients. Neurosci Lett., 215: 5-8. 